\title{
LID Facility Layout and Hydrologic Impact Simulation in an Expressway Service Area
}

\author{
Jianping Gao ${ }^{1}$, Junkui Pan ${ }^{1 *}$, Ruoyu Tang ${ }^{1}$, Shasha Guo ${ }^{1}$, Yan Liu ${ }^{2}$ \\ ${ }^{1}$ School of Civil Engineering, Chongqing Jiaotong University, Chongqing, China \\ ${ }^{2}$ School of Economics and Management, Chongqing Jiaotong University, Chongqing, China
}

Received: 22 November 2017

Accepted: 18 October 2018

\begin{abstract}
In order to solve the problem of rainwater discharge in expressway service areas, low-impact development (LID) facilities are arranged systematically in an expressway service area in China. A storm rainwater management model is applied to simulate the hydrologic process so as to analyze the influence of a bioretention area on rainfall runoff regulation under three LID situations: separate bioretention, bioretention and permeable pavement in-series, and bioretention, permeable pavement, and grass swales in-series. Based on the results, increasing the ratio of bioretention area to drainage area increases the average values of runoff reduction rate, runoff peak reduction rate, and runoff peak delay time under five types of rainfall. The results indicate that permeable pavement can significantly reduce the hydraulic load of bioretention while grass swales have little effect. Under different rainfall levels, the runoff reduction rate of the LID service area increases by $16.16-68.41 \%$, the runoff peak reduction rate increases by $49.31-59.07 \%$, and the runoff peak delay time increases by up to 326 min compared with a traditional service area.
\end{abstract}

Keywords: LID; SWMM; rainwater runoff; hydrologic performance

\section{Introduction}

With the rapid development of China's expressway network, the high demand for expressway service areas is also increasing [1]. However, impervious areas such as roofing and hardened pavement constitute over $70 \%$ of the expressway service area, which leads to reduced rainfall infiltration and destruction of the natural hydrological balance as well as many rainwater discharge problems [2]. In addition, expressway service areas involve a large number of motor vehicles, so rainwater runoff typically contains many pollutants, including

*e-mail: 15303950218@163.com suspended solids (SS), chemical oxygen demand (COD), heavy metals, nutrients $(\mathrm{P}, \mathrm{N})$, petroleum, etc. [3-4], which have serious adverse impacts on the regional water environment.

Low-impact development (LID), proposed in the United States, uses natural landscape elements such as bioretention cells, permeable pavement, and grass swales to achieve decentralized treatment of rainwater runoff at its source; this allows for rapid storage, infiltration, and evaporation of water to achieve runoff reduction and rainwater recycling [5-6]. Relevant studies have shown that LID measures have good hydrological performance. Wilson et al. [7], Fassman et al. [8], Dietz et al. [9], Bedan et al. [10], and Wang et al. [11] studied differences between LID and a traditional drainage 
system and proved that the addition of LID measures can effectively alleviate runoff discharge pressure in the study area. Gao et al. [12], Roseen et al. [13], Sun et al. [14], and Li et al. [15] simulated and analyzed the runoff treatment effect of different LID units under different rainfall frequencies and showed that the rainwater treatment effect of LID measures was better under higher-frequency rainfall conditions. To date, LID technologies have developed rapidly in domestic and foreign urban stormwater treatments [16-17].

Existing studies on LID have mainly concentrated on urban areas [18-20], while research on rainwater ecological disposal is relatively lacking in expressway service areas. Although $\mathrm{Xu}$ et al. [21] and Chen et al. [22] have proposed the concept of building an LID service area, they did not evaluate the hydrological performance of the LID service area. In addition, most studies typically have only evaluated individual LID practices [23-25], but runoff treatment performance of LID practices in-series have rarely been monitored. The series use of LID drainage measures to form an organic rainwater ecological drainage system is a problem that remains to be solved [26-27]. Meanwhile, by studying the effects of stormwater treatment under different LID series measures, a reference can be provided as to the role played by different LID measures and for improving the performance of stormwater runoff treatment.

The objectives of the present study are to select and arrange LID facilities according to the site characteristics of an expressway service area in China, and to use SWMM to evaluate the runoff treatment performance of different LID practices in-series. Then, the study comprehensively compares hydrological performance between LID and traditional service areas, providing a reference for the ecological construction of expressway service areas.

\section{Material and Methods}

\section{Ecological Treatment Technology for Rainwater Runoff in Expressway Service Areas}

LID facilities such as bioretention, grass swales, permeable pavement, and other rainwater control facilities have been widely used in the construction of "sponge city" in China, which has showed effective performance in regulating regional runoff and purifying water. Because expressway service areas in China have no clear specifications or method for ecological rainwater treatment, based on the construction concept of "sponge city," LID facilities were arranged systematically according to the vertical field conditions and the green areas within the expressway service area so to achieve organized drainage of rainwater runoff on site [28].

The LID facilities in the expressway service area are arranged as follows:

1) The parking area and road area in the expressway service area is largest, generally accounting for more than $50 \%$ of the total area, and the runoff coefficient a)

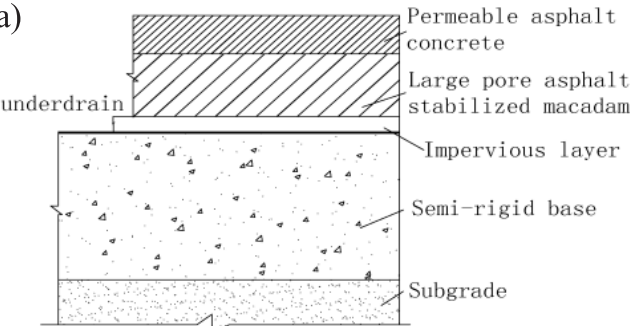

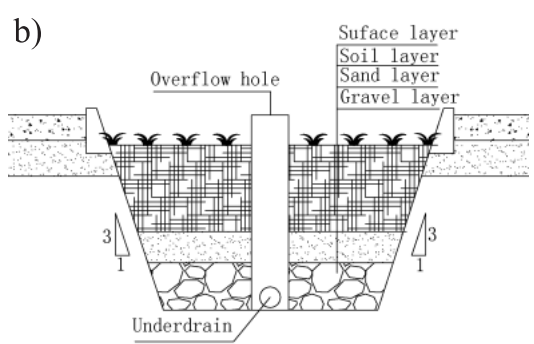

c)

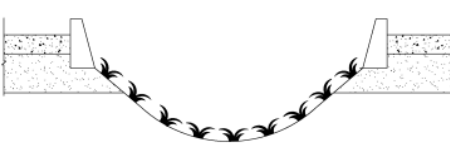

Fig. 1. LID facilities: a) Permeable asphalt pavement, b) Bioretention, c) Grass swales.

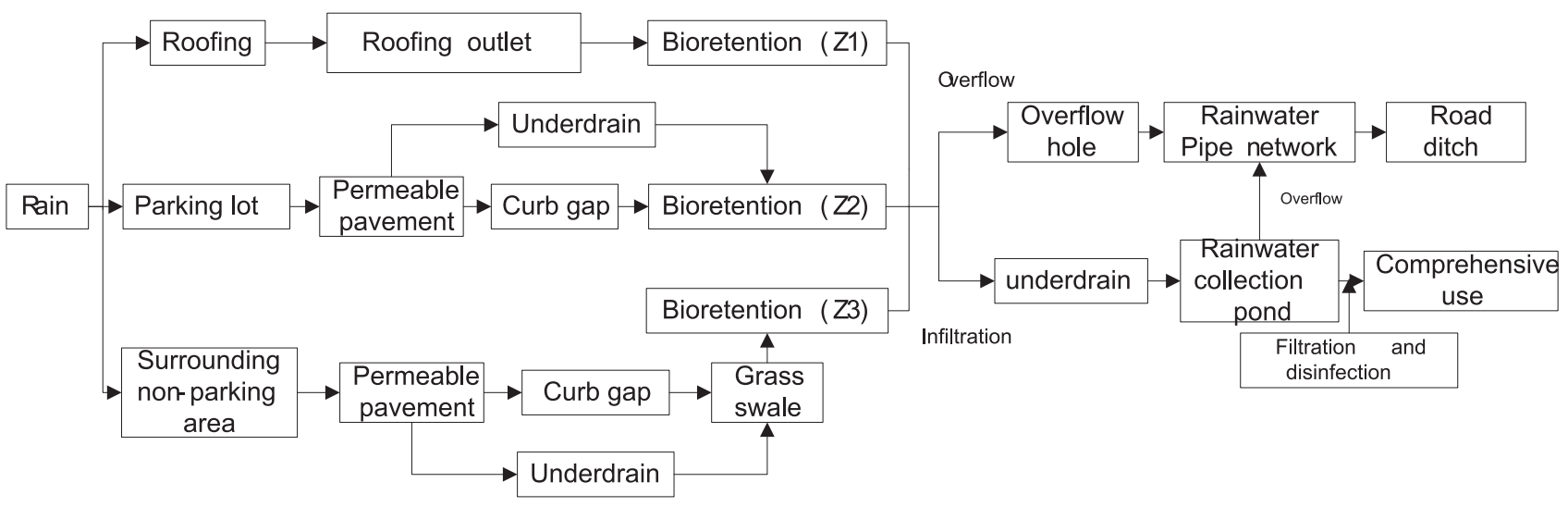

Fig. 2. Schematic diagram of rainwater runoff path in the LID expressway service area. 
is relatively high in this zone, so the parking lot and hardened pavement can be replaced by permeable asphalt pavement in order to reduce peak flow and runoff volume.

2) The runoff of parking lots and roofing can permeate, and be transported and purified by bioretention in the middle of parking lots and around buildings in order to reduce the runoff volume and improve the landscape effect.

3) In refueling areas and surrounding areas, there are large catchment areas with large drainage pressures, so bioretention and grass swales can be used to conduct runoff transmission and volume control.

LID facilities and rainwater runoff paths are shown in Figs 1 and 2.

\section{SWMM Model}

\section{Introduction}

The storm rainwater management model (SWMM) is a comprehensive mathematical model developed by the U.S. Environmental Protection Agency for the design and management of urban rainwater. The SWMM model consists of two modules: surface runoff calculation and LID. The surface runoff calculation module adopts a nonlinear reservoir method. By simultaneously adopting the continuity equation and the Manning equation, the surface runoff generated by each sub-catchment area was calculated. The LID module provides five decentralized rainwater treatment technologies such as bioretention, permeable pavement, infiltration trenches, rain barrels, and grass swales [29]. Through the simulation of hydrologic processes such as storage, infiltration, evaporation, and so on, the performance of LID facilities on runoff volume reduction, runoff peak reduction, and runoff peak delay is determined [30]. Due to its powerful modelling capabilities, SWMM has been widely used in the design of urban drainage systems and the design and calculation of stormwater control measures worldwide [14].

\section{Overview of the Study Region}

An expressway service area in Sichuan Province in China was used as the study area. Its area is $18,503.1 \mathrm{~m}^{2}$, and its impervious area is composed of roofing, parking lots, traffic roads, and fueling areas, accounting for $88.3 \%$ of the total area. The service area is topographically higher to the northeast and lower to the southwest, with a slope of $2 \%$. Rainwater runoff discharges into the stormwater inlet along the vertical and horizontal slopes and then into the roadside ditch. The hardened area of the site is large and the comprehensive runoff coefficient is approximately 0.8 , resulting in a large runoff effluent load. In addition, a large amount of rainwater runoff is discharged without effective use, resulting in a waste of rainwater resources. Therefore, based on the above study, LID facilities are arranged in this expressway service area systematically. The LID facilities layout plan in the service area is shown in Fig. 3.

\section{Simulation Scenarios}

As shown in Fig. 2, the service area rainwater flows into bioretention in three types of runoff paths, namely: (1) hardened roofing $\rightarrow$ bioretention; (2) parking lot permeable pavement $\rightarrow$ bioretention; (3) permeable pavement in surrounding non-parking areas $\rightarrow$ grass swales $\rightarrow$ bioretention. The bioretention of three types of runoff paths were numbered $\mathrm{Z1}, \mathrm{Z} 2$, and $\mathrm{Z} 3$, respectively. Five ratios $(5 \%, 10 \%, 15 \%, 20 \%$, and $24 \%$ ) of bioretention areas to drainage areas were used to study the influence of bioretention areas on rainfall runoff regulation under three types of runoff paths.

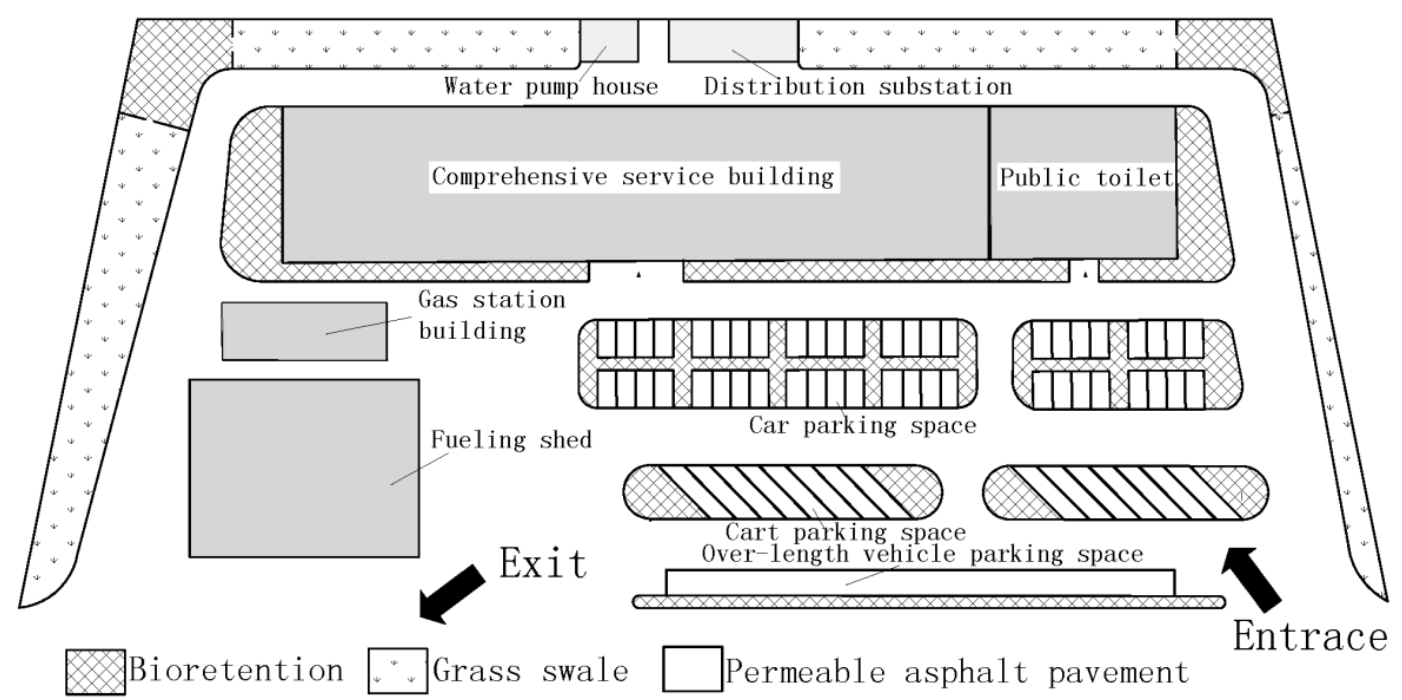

Fig. 3. Layout of LID facilities in the expressway service area. 
Then the bioretention area was selected to be applied to the study area based on the target values of stormwater runoff treatment according to the rainfall characteristics and site conditions. Finally, the hydrologic performance of LID service areas was evaluated comprehensively.

Therefore, five hydrologic scenarios were simulated: (1) bioretention under the influence of roof runoff; (2) permeable pavement and bioretention in series under the influence of parking lot runoff; (3) permeable pavement, grass swales, and bioretention in series under the influence of surrounding non-parking area runoff; (4) traditional expressway service areas; and (5) LID expressway service areas. (1), (2), and (3) were pursued to obtain the optimal bioretention area under three types of runoff paths, while (4) and (5) were pursued to comprehensively evaluate the hydrologic performance of LID facilities.

\section{Study Area Generalization}

When generalizing the study area, it is necessary to consider not only the differences in regional site characteristics but also the distribution of drainage pipes. As an expressway service area is relatively small and pipeline distance is relatively short, the influence of a drainage pipe on hydrologic progress can be neglected. For service areas without LID facilities, the study area could be generalized to a sub-catchment area and a drain node. For a service area with LID facilities, the division method of the sub-catchment area was as follows: (a) bioretention and grass swales were each considered as sub-catchment areas; and (b) parking lots, roofing, fueling areas, and surrounding roads were divided into sub-catchment areas according to the runoff path. According to the above division method, the LID service area was divided into 22 sub-catchment areas and one outfall.

\section{Design Rainfall}

According to the hydrological and meteorological dates of the study area, five types of design rainfall with different durations and intensities (as shown in Table 1) were selected.

The Chicago rainstorm model is a non-constant rainfall scenario synthesis method widely used in urban drainage design, and its application effects have been

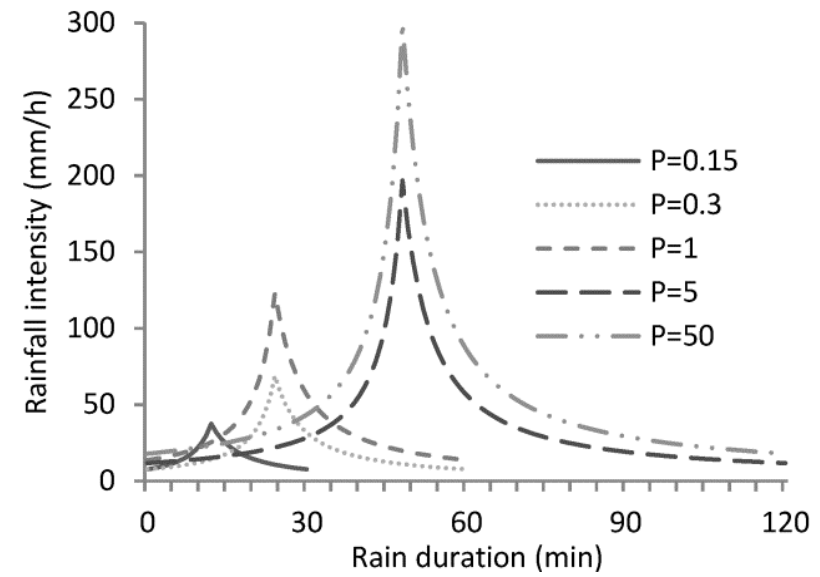

Fig. 4. Chicago rainstorm process lines for five types of rainfall.

confirmed [31]. In the Chicago rainstorm model, the rainfall return period $(\mathrm{P})$ reflects the maximum value of rainfall intensity, and the rainfall peak coefficient (r) determines the arrival time of maximum rainfall intensity. The five types of design rainfalls in Table 1 were transformed into Chicago rainstorm process lines, and the rainfall peak coefficient was 0.4 [32]. The typical Chicago rainstorm process lines of the five design rainfalls are shown in Fig. 4.

\section{Model Parameters}

The SWMM model parameters are divided into three categories: hydrologic and hydraulic parameters, water quality parameters and LID parameters. The model parameters can be classified into deterministic and nondeterministic parameters according to the methods through which they are obtained. Deterministic parameters can be obtained directly from the related literature and field monitoring data. Nondeterministic parameters can be obtained according to the typical range of parameter values given by the SWMM user manual and related literature, but parameter calibration and validation are required [33-34].

1) Calibration and validation of hydrologic and hydraulic parameters.

In this SWMM simulation, the Horton infiltration model was used to simulate the rainfall infiltration process and the runoff concentration model adopted the

Table 1. Design rainfall.

\begin{tabular}{|c|c|c|c|c|c|}
\hline Rainfall number & Duration $(\mathrm{h})$ & Amount $(\mathrm{mm})$ & Average intensity $(\mathrm{mm} / \mathrm{h})$ & Return period (a) & Level \\
\hline 1 & 0.5 & 8.08 & 16.16 & 0.15 & Light \\
\hline 2 & 1 & 19.88 & 19.88 & 0.3 & Moderate \\
\hline 3 & 1 & 35.61 & 35.61 & 1 & Heavy \\
\hline 4 & 2 & 72.46 & 36.23 & 5 & Rainstorm \\
\hline 5 & 2 & 110.51 & 55.26 & 50 & Heavy rainstorm \\
\hline
\end{tabular}


Table 2. Runoff coefficient ranges of different underlying surfaces.

\begin{tabular}{|c|c|}
\hline Type of Underlying Surface & $\begin{array}{c}\text { Runoff } \\
\text { Coefficient } \\
\text { Range }\end{array}$ \\
\hline Roofing, concrete, or asphalt pavement & $0.85-0.95$ \\
\hline $\begin{array}{c}\text { Boulder paving pavement and asphalt surface } \\
\text { treatment with Macadam pavement }\end{array}$ & $0.55-0.65$ \\
\hline Graded broken stone pavement & $0.40-0.50$ \\
\hline Dry masonry or Macadam pavement & $0.35-0.40$ \\
\hline Unpaved & $0.25-0.35$ \\
\hline Parks or green spaces & $0.10-0.20$ \\
\hline
\end{tabular}

nonlinear reservoir model. The hydrologic and hydraulic parameters that needed to be calibrated and validated were mainly the Manning coefficients of permeable surfaces and impervious surfaces, the water storage capacity of permeable surfaces and impervious surfaces, and maximum and minimum infiltration rates and the attenuation coefficient in the Horton infiltration model.

According to the runoff coefficient method of Liu [35], the model parameters were calibrated by a Chicago synthetic rainfall (P2) with a rainfall peak coefficient of 0.4 , a rainfall duration of $2 \mathrm{~h}$, and a return period of 2 years. The calibrated parameters were validated by the Chicago synthetic rainfall (P1) and (P3) with a rainfall peak coefficient of 0.4 , a rainfall duration of $2 \mathrm{~h}$, and return periods of 1 and 3 years, respectively.

The surface area of the traditional expressway service area includes roofing, asphalt pavement, and green space. According to the runoff coefficient ranges of different underlying surfaces shown in Table 2, the method of area-weighted averaging was used to obtain the comprehensive runoff coefficient of the traditional expressway service area based on the area proportion of different underlying surfaces. The calculation result was the range of $0.76-0.86$.

Through the calibration of model parameters, the runoff coefficient of rain (P2) in the SWMM simulation was found to be 0.822 , which was within the range of comprehensive runoff coefficients of 0.76-0.86. Through the validation of model parameters, the runoff coefficients of rain (P1) and rain (P3) in the SWMM simulation were 0.807 and 0.828 , respectively, which also were within the range of comprehensive runoff coefficients, indicating that the model parameters had good adaptability. The calibration and validation results for hydrologic and hydraulic parameters are shown in Table 3. The rainfall runoff process lines of rain (P2), rain (P1), and rain (P3) are shown in Fig. 5.

2) LID parameters.

This SWMM simulation defined three types of LID facilities: bioretention, permeable asphalt pavement, and grass swales. The main parameters of the LID facilities were obtained through design specifications and measured data, as shown in Table 4.

\section{Results and Discussion}

\section{Impact of Bioretention Area Ratio on Hydrologic Performance}

McCuen [36] proposed three indicators for evaluating the hydrologic performance of LID facilities: (a) runoff reduction rate; (b) runoff peak reduction rate; and (c) runoff peak delay time. Under the five types of design rainfall, the influence of bioretention $\mathrm{Z1}, \mathrm{Z} 2$, and $\mathrm{Z} 3$ area ratios on the average runoff reduction rate, average runoff peak reduction rate, and average runoff peak delay time are shown in Fig. 6(a-c), respectively.

In order to restore the hydrologic balance of the expressway service area to pre-development conditions, the LID facilities must achieve a certain regulation performance for rainfall runoff; that is, they must meet the target values of the above three indicators. The target values for runoff volume reduction and runoff peak reduction were based on the comprehensive runoff coefficient change before and after regional development [37]. The runoff peak delay time target values could be determined according to the Kerby formula (Equation 1).

Table 3. Calibration and validation results for hydrological and hydraulic parameters.

\begin{tabular}{|c|c|c|}
\hline Parameter type & Parameter name & Calibration and validation results \\
\hline \multirow{3}{*}{ Horton model } & Maximum infiltration rate $(\mathrm{mm} / \mathrm{h})$ & 78.1 \\
\cline { 2 - 3 } & Minimum infiltration rate $(\mathrm{mm} / \mathrm{h})$ & 3.80 \\
\cline { 2 - 3 } & Attenuation constant $\left(\mathrm{h}^{-1}\right)$ & 0.2 \\
\hline \multirow{2}{*}{ Manning's roughness coefficient } & Impervious area Manning's roughness & 0.013 \\
\cline { 2 - 3 } & Permeable area Manning's roughness & 0.30 \\
\hline \multirow{3}{*}{ Surface depression } & Impervious area depression storage(mm) & 2.1 \\
\cline { 2 - 3 } & Permeable area depression storage (mm) & 5.0 \\
\cline { 2 - 3 } & Percent of impervious area with no depression storage (\%) & 10 \\
\hline
\end{tabular}


a)

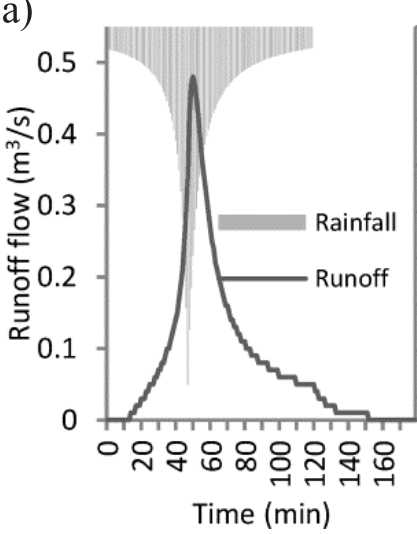

b)

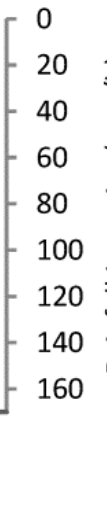

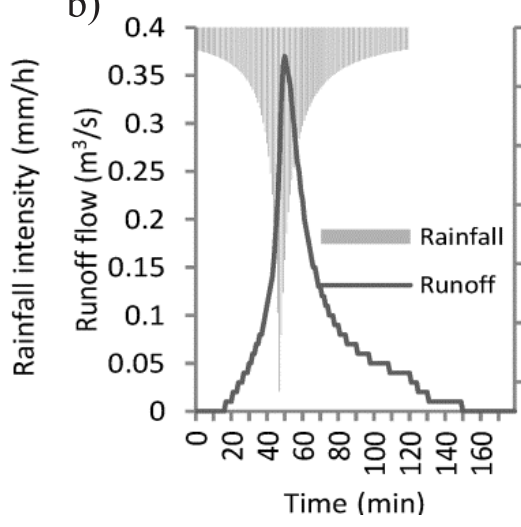

c)

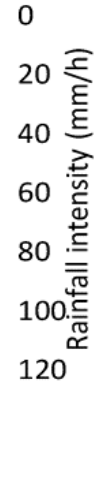

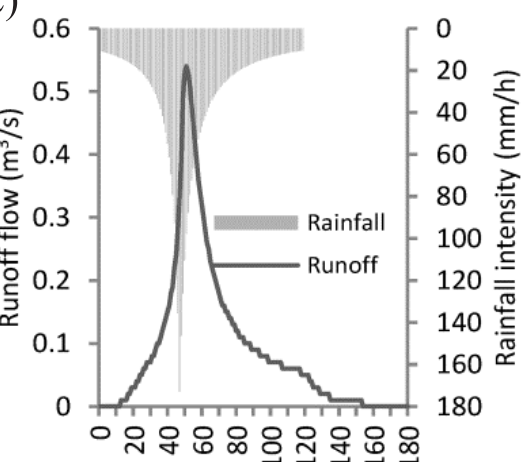

Time (min)

Fig. 5. Rainfall runoff process lines: a) Rain(P2), b) Rain(P1), c) Rain(P3).

Table 4. Parameters of bioretention, permeable asphalt pavement, and grass swales.

\begin{tabular}{|c|c|c|c|}
\hline LID facility types & Facility structures & Facility parameters & Value \\
\hline \multirow{11}{*}{ Bioretention } & \multirow{2}{*}{ Surface layer } & Water storage depth $(\mathrm{mm})$ & 150 \\
\hline & & Surface slope (\%) & 0 \\
\hline & \multirow{3}{*}{ Soil layer } & Thickness (mm) & 700 \\
\hline & & Porosity & 0.44 \\
\hline & & Permeability $(\mathrm{mm} / \mathrm{h})$ & 30 \\
\hline & \multirow{3}{*}{ Storage water layer } & Thickness (mm) & 300 \\
\hline & & Void ratio & 0.66 \\
\hline & & Seepage rate $(\mathrm{mm} / \mathrm{h})$ & 3.3 \\
\hline & \multirow{3}{*}{ Underdrain } & Flow coefficient $(\mathrm{mm} / \mathrm{h})$ & 6.25 \\
\hline & & Flow exponent & 0.5 \\
\hline & & Offset height (mm) & 100 \\
\hline \multirow{11}{*}{ Permeable pavement } & \multirow{2}{*}{ Surface layer } & Water storage depth $(\mathrm{mm})$ & 3 \\
\hline & & Surface slope (\%) & 2 \\
\hline & \multirow{3}{*}{ Pavement layer } & Thickness (mm) & 100 \\
\hline & & Void ratio & 0.35 \\
\hline & & Permeability $(\mathrm{mm} / \mathrm{h})$ & 250 \\
\hline & \multirow{3}{*}{ Storage water layer } & Thickness (mm) & 100 \\
\hline & & Void ratio & 0.66 \\
\hline & & Seepage rate $(\mathrm{mm} / \mathrm{h})$ & 0 \\
\hline & \multirow{3}{*}{ Underdrain } & Flow coefficient $(\mathrm{mm} / \mathrm{h})$ & 2.08 \\
\hline & & Flow exponent & 0.5 \\
\hline & & Offset height (mm) & 30 \\
\hline \multirow{3}{*}{ Grass swales } & \multirow{3}{*}{ Surface layer } & Water storage depth $(\mathrm{mm})$ & 150 \\
\hline & & Surface slope (\%) & 2 \\
\hline & & Swale side slope & 5 \\
\hline
\end{tabular}



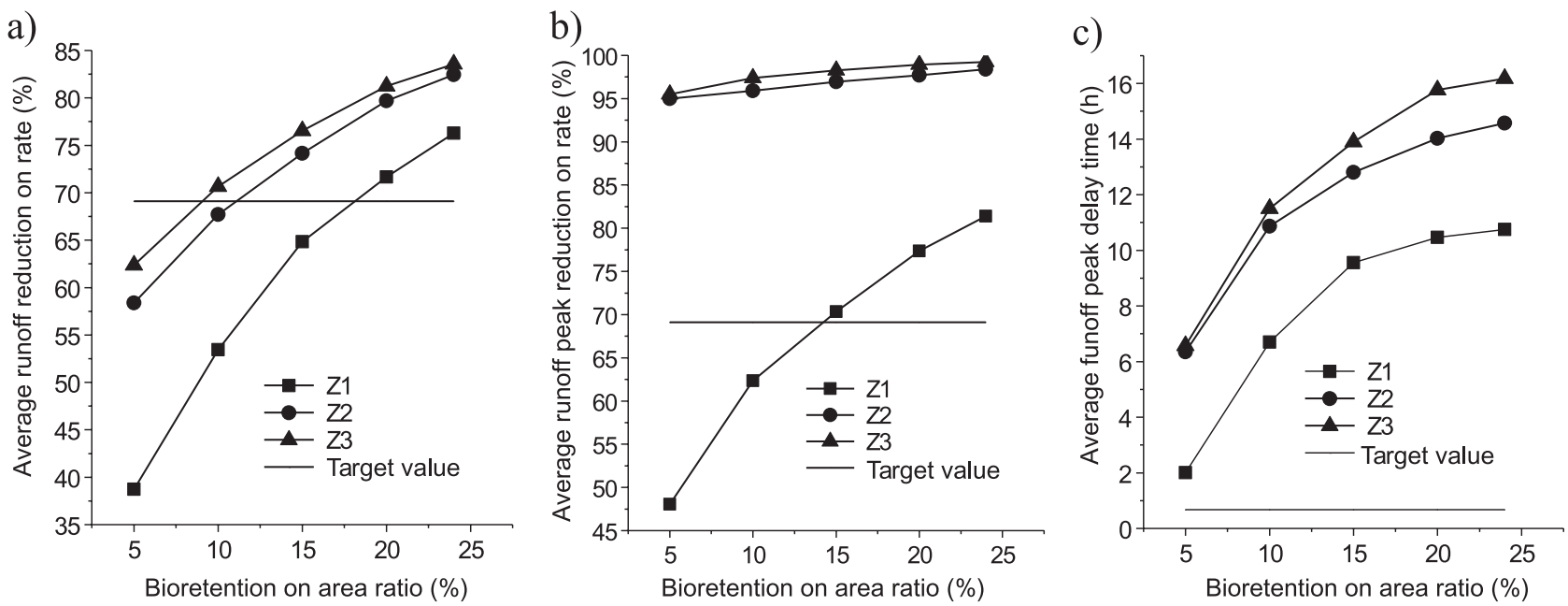

Fig. 6. Influence of bioretention $\mathrm{Z1}, \mathrm{Z} 2$, and $\mathrm{Z} 3$ area ratios on rainfall runoff regulation under four types of rainfall: a) Rainfall runoff reduction rate, b) Rainfall runoff peak reduction rate, c) Rainfall runoff peak delay time.

$$
t=1.445\left(\frac{n L_{s}}{\sqrt{i_{s}}}\right)^{0.467}
$$

...where $t$ is the sheet flow time of concentration (min); $L_{S}$ is flow length (m); $i_{S}$ is drainage area slope; $n$ is Manning's roughness; and the woodland value is 0.80 .

As shown in Fig. 6, with the increasing ratio of bioretention area to drainage area, the average value of runoff reduction rate, runoff peak reduction rate, and runoff peak delay time all increased. The permeable pavement could reduce the hydraulic load of bioretention to a certain extent, prolong the arrival time of the runoff peak, and significantly reduce peak flow. Therefore, when permeable pavement is used, the bioretention area ratio can be reduced appropriately. Grass swales had little effect on the total runoff volume and runoff peak, but had a certain effect on runoff peak delay due to the increase in runoff transmission paths, thereby prolonging the arrival of the runoff peak.

The study area was woodland before development and the runoff coefficient $\left(c_{1}\right)$ was 0.25 , while the comprehensive runoff coefficient $\left(\mathrm{c}_{2}\right)$ was 0.81 after development, so the target values for runoff volume reduction rate and runoff peak reduction rate were both $\left(c_{2}-c_{1}\right) / c_{2}=69.1 \%$. As shown in Fig. 6a) and b), in order to meet the target runoff volume and runoff peak, when bioretention was used separately, the area ratio can be as large as $18 \%$, while when bioretention was arranged in series with permeable pavement or in series with

Table 5. Simulation results for a traditional service area and LID service area under different design rainfall levels

\begin{tabular}{|c|c|c|c|c|c|c|c|c|c|c|}
\hline $\begin{array}{c}\text { Rainfall } \\
\text { level }\end{array}$ & $\begin{array}{c}\text { Design } \\
\text { scenario }\end{array}$ & $\begin{array}{c}\text { Rainfall } \\
(\mathrm{mm})\end{array}$ & $\begin{array}{l}\text { Runoff } \\
(\mathrm{mm})\end{array}$ & $\begin{array}{l}\text { Runoff } \\
\text { reduction } \\
\text { rate }(\%)\end{array}$ & $\begin{array}{c}\text { Rainfall } \\
\text { intensity } \\
\text { peak } \\
(\mathrm{mm} / \mathrm{min})\end{array}$ & $\begin{array}{c}\text { Runoff } \\
\text { peak } \\
(\mathrm{mm} / \mathrm{min})\end{array}$ & $\begin{array}{c}\text { Runoff } \\
\text { peak } \\
\text { reduction } \\
\text { rate }(\%)\end{array}$ & $\begin{array}{l}\text { Rainfall } \\
\text { peak } \\
\text { moment }\end{array}$ & $\begin{array}{l}\text { Runoff } \\
\text { peak } \\
\text { moment }\end{array}$ & $\begin{array}{c}\text { Runoff } \\
\text { peak delay } \\
\text { time (min) }\end{array}$ \\
\hline \multirow{2}{*}{ Light } & Traditional & \multirow{2}{*}{8.08} & 5.53 & 31.59 & \multirow{2}{*}{0.62} & 0.20 & 67.68 & \multirow{2}{*}{$0: 12$} & $0: 21$ & 9 \\
\hline & LID & & 0 & 100 & & 0 & 100 & & 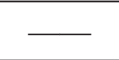 & 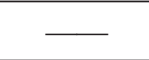 \\
\hline \multirow{2}{*}{ Moderate } & Traditional & \multirow{2}{*}{19.88} & 15.82 & 20.40 & \multirow{2}{*}{1.15} & 0.57 & 50.35 & \multirow{2}{*}{$0: 24$} & $0: 29$ & 5 \\
\hline & LID & & 0 & 100 & & 0 & 100 & & 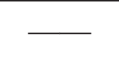 & - \\
\hline \multirow{2}{*}{ Heavy } & Traditional & \multirow{2}{*}{35.16} & 29.46 & 16.76 & \multirow{2}{*}{2.05} & 1.17 & 42.99 & \multirow{2}{*}{$0: 24$} & $0: 27$ & 3 \\
\hline & LID & & 7.85 & 77.97 & & 0.02 & 98.92 & & $5: 59$ & 335 \\
\hline \multirow{2}{*}{ Rainstorm } & Traditional & \multirow{2}{*}{72.46} & 62.05 & 14.37 & \multirow{2}{*}{3.28} & 2.05 & 37.62 & \multirow{2}{*}{$0: 48$} & $0: 51$ & 3 \\
\hline & LID & & 42.09 & 41.91 & & 0.43 & 86.90 & & $0: 54$ & 6 \\
\hline \multirow{2}{*}{$\begin{array}{l}\text { Heavy } \\
\text { rainstorm }\end{array}$} & Traditional & \multirow{2}{*}{110.5} & 97.16 & 12.08 & \multirow{2}{*}{5.00} & 3.32 & 33.54 & \multirow{2}{*}{$0: 48$} & $0: 50$ & 2 \\
\hline & LID & & 79.31 & 28.24 & & 0.88 & 82.32 & & $0: 51$ & 3 \\
\hline
\end{tabular}

Note: ,-" means no runoff. 
permeable pavement and grass swales, the area ratio can be as large as $10 \%$. According to the Kerby formula, the target value of runoff peak delay time was $40 \mathrm{~min}$ and, according to Fig. 6c), the three scenarios all met the target value requirements.

\section{Analysis of Runoff Simulation Results for a Rraditional Service Area and an LID Service Area}

According to the above analysis, the area ratio for bioretention $\mathrm{Z} 1$ was set to $18 \%$ and the area ratios for bioretention $\mathrm{Z} 2$ and $\mathrm{Z} 3$ were set to $10 \%$. The SWMM model was used to simulate the hydrologic response for traditional service areas and LID service areas under different rainfall levels; results are shown in Table 5.

As shown in Table 5, under different rainfall levels, the runoff reduction rate for the traditional service area ranged from $12.08 \%$ to $31.59 \%$, the peak reduction rate ranged from $33.01 \%$ to $40.93 \%$, and the peak delay time ranged from $2 \mathrm{~min}$ to $9 \mathrm{~min}$. After the addition of LID facilities, the runoff reduction rate ranged from $28.24 \%$ to $100 \%$, the peak reduction rate ranged from $82.32 \%$ to $100 \%$, and the peak delay time was up to $335 \mathrm{~min}$. Compared with the traditional service area, the runoff load of the LID service area was reduced to a certain extent.

In addition, in cases of light rain and moderate rain, the LID service area had almost no runoff. However, with increasing rainfall levels, the performance of LID facilities on runoff reduction and hysteresis would be weakened and the greater the rainfall level, the closer the hydrologic conditions to the traditional service area.

\section{Conclusions}

Based on the SWMM model, the effects of LID facilities on stormwater runoff regulation in an expressway service area were studied and the following conclusions were drawn.

With increasing ratios of bioretention area to drainage area, the average values for runoff reduction rate, runoff peak reduction rate, and runoff peak delay time all increased. The permeable pavement could effectively reduce the bioretention area ratio while grass swales had little impact. Brown et al. [26] compared the hydrological performance of bioretention with that of bioretention and permeable pavement in series and showed that LID practices in series treated an additional $10 \%$ of annual runoff volume, discharged approximately half the outflow volume, and discharged significantly lower peak outflow rates compared with a single treatment practice (bioretention). This conclusion is consistent with the conclusion that permeable pavement can significantly reduce bioretention area rates in the present study. However, grass swales were not considered in the previous study.
Compared with the traditional service area, the runoff reduction rate increased by $16.16-68.41 \%$, the peak reduction rate increased by $49.31-59.07 \%$, and the peak delay time increased by up to 326 min under different rainfall levels in the LID service area. Li et al. [15] showed that the total runoff reduction rate increased by $25.69-42.20 \%$, the peak reduction rate increased by $38.64-44.46 \%$, and the peak delay time increased by 5-7 min after a $2 \%$ bioretention area was set up in the study area under a rainfall return period of 2-20 years. This was significantly less than the runoff regulation ability of the LID measures in the present study. This was because of the fact that only bioretention was considered in Li's study; permeable pavement and grass swales were not considered. Additionally, the underlying surface and rainfall conditions of the study areas were different, which also resulted in differences in the runoff regulation capacity of LID.

With increasing rainfall level, the effects of LID measures on runoff regulation were weakened and the larger the rainfall level, the closer the LID service area was to the traditional service area in performance terms. Li et al. [15] studied the runoff regulation performance of urban rainwater gardens and showed that, similarly, the runoff regulation performance of rainwater gardens weakened with increased rainfall intensity.

LID measures have very strong application value in solving the problem of rainwater discharge in expressway service areas but should be selected appropriately and arranged according to different service area types, soil conditions, and rainfall characteristics. Meanwhile, other LID measures can be considered in future research such as green roofs, plant buffers, etc.

\section{Acknowledgements}

This work was supported by the National Natural Science Foundation of China (No. 51378520) and the National Natural Science Foundation of Chongqing (No. cstc2018jcyjAX0445).

\section{Conflict of Interest}

This manuscript has not been published or presented elsewhere in part or in entirety and is not under consideration by another journal. We have read and understood your journal's policies, and we believe that neither the manuscript nor the study violates any of these. There are no conflicts of interest to declare.

\section{References}

1. CHEN W.F. Sustainable development and ecological management of expressway service area. Modern Economic Information, 8X, 20, 2013 [In Chinese].

2. LI P.F. Study on rainwater utilization technology in expressway service area-taking Xinyang expressway 
service area as an example. Chang'an University, Xi'an, China, 2011 [In Chinese].

3. LIN Q. Study on characteristics of wastewater in expressway service area. Energy and Environment, 1, 14, 2013 [In Chinese].

4. YE Y., XU P.B., ZHAI Y.B., CHEN L. Characterization of highway runoff pollution. Environmental Science and Technology, 36 (6), 134, 2013.

5. BROWN R.A., HUNT W.F., ASCE M. Impacts of construction activity on bioretention performance. Journal of Hydrologic Engineering, 15 (15), 386, 2010.

6. BROWN R.A., SKAGGS R.W., LII W.F.H. Calibration and validation of DRAINMOD to model bioretention hydrology. Journal of Hydrology, 486 (486), 430, 2013.

7. WILSON C.E., HUNT W.F., WINSTON R.J., SMITH P. Comparison of runoff quality and quantity from a commercial low-impact and conventional development in Raleigh, North Carolina. Journal of Environmental Engineering, 141 (2), 05014005, 2015.

8. FASSMAN E.A., BLACKBOURN S. Urban runoff mitigation by a permeable pavement system over impermeable soils. Journal of Hydrologic Engineering, 15 (6), 475, 2010.

9. DIETZ M.E., CLAUSEN J.C. Storm water runoff and export changes with development in a traditional and low impact subdivision. Journal of Environmental Management, 87 (4), 560, 2008.

10. BEDAN E.S., CLAUSEN J.C. Stormwater runoff quality and quantity from traditional and low impact development watersheds. Journal of the American Water Resources Association, 45 (4), 998, 2009.

11. WANG W.W., ZHAO Z.J., QIN H.P. Hydrological effect assessment of low impact development for urbanized area based on SWMM. Acta Scientiarum Naturalium Universitatis Pekinensis, 48 (2), 303, 2012 [In Chinese].

12. GAO J.P., PAN J.K., XIE Y.C. Effects of bioretention structural layer parameters on detention and retention for road runoff. Water Science \& Technology, 28 (5), 702, 2017 [In Chinese].

13. ROSEEN R.M., BALLESTERO T.P., HOULE J.J., AVELLANEDA P., BRIGGS J. Seasonal performance variations for storm-water management systems in cold climate conditions. Journal of Environmental Engineering, 135 (3), 128, 2009.

14. SUN Y.W., POMEROY C.A., LÜ S.B., XU C.D. Hydrological regulation performances of LID practices based on different rainfall reappearance periods. Transactions of the Chinese Society for Agricultural Machinery, 47 (6), 178, 2016 [In Chinese].

15. LI J.K., LI Y., SHEN B., LI Y. J. Simulation of rain garden effects in urbanized area based on SWMM. Journal of Hydroelectric Engineering, 33 (4), 60, 2014 [In Chinese].

16. ZHANG J.Y., WANG Y.T., HU Q.F., HE R.M. Discussion and views on some issues of the sponge city construction in China. Advances in Water Science, 27 (6), 793, 2016 [In Chinese].

17. CHANG N.B. Hydrological connections betweenlowimpact development, watershed best management practices, and sustainable development. Journal of Hydrologic Engineering 15 (6), 384, 2010.

18. TOBIO J.A.S., MANIQUIZ-REDILLAS M.C., KIM L.H. Application of SWMM in evaluating the reduction performance of urban runoff treatment systems with varying land use. International Low Impact Development, 11, 2015.
19. HU A.B., REN X.X., YU S.W., DING N. Exploration for creating low-impact development stormwater management demonstration area in Shenzhen. China Water \& Wastewater, 26 (20), 69, 2010 [In Chinese].

20. BAEK S.S., CHOI D.H., JUNG J.W., LEE H.J., LEE, H., YOON K.S., CHO K.H. Optimizing low impact development (lid) for stormwater runoff treatment in urban area, korea: experimental and modeling approach. Water Research, 86, 122, 2015.

21. XU L., REN X.S., WANG D., CHEN L., LI Y. Study on the construction of green sustainable development service area in expressway. Industrial Safety and Environmental Protection, 43 (2), 77, 2017 [In Chinese].

22. CHEN J. High-speed service area rainwater recycling product research and design. Zhejiang Sci-Tech University, China, 2011 [In Chinese].

23. LUCKE T., MOHAMED M.A.K., TINDALE N. Pollutant removal and hydraulic reduction performance of field grassed swales during runoff simulation experiments. Water, 6 (7), 1887, 2014.

24. FASSMAN E.A., BLACKBOUN S. Urban runoff mitigation by a permeable pavement system over impermeable soils. Journal of Hydrologic Engineering, 15 (6), 475, 2010.

25. GÜLBAZ S., KAZEZYILMAZ-ALHAN C.M. Hydrological model of lid with rainfall-watershedbioretention system. Water Resources Management, 31 (6), 1931, 2017.

26. BROWN R.A., LINE D.E., LII, W.F.H. Lid treatment train: pervious concrete with subsurface storage in series with bioretention and care with seasonal high water tables. Journal of Environmental Engineering, 138 (6), 689, 2012.

27. KUANG B., OUYANG E.M., WANG T. Runoff control by Green rainwater drainage system in residential area based on LID. China Water \& Wastewater, 31 (23), 134, 2015 [In Chinese].

28. LIU C., WANG W.L., LI J.Q., SU L.P., WANG Q., ZHANG Y. Application and case analysis of low impact development technology of ecological parking. Construction Science and Technology, 11(7), 52, 2015 [In Chinese].

29. AlFREDO K., MONTAlTO F., GOLdSTEIN A. Observed and modeled performances of prototype green roof test plots subjected to simulated low-and highintensity precipitations in a laboratory experiment. Journal of Hydrologic Engineering, 15(6), 444, 2010.

30. WANG W.L., Li J.Q., GONG Y.W., ZHU M.J., ZANG Q.K. LID stormwater control effect simulation based on SWMM. China Water \& Wastewater, 28 (21), 42, 2012 [In Chinese].

31. ZHANG D.W., ZHAO D.Q, CHEN J.N. Application of Chicago rain process line model in drainage system simulation. Water \& Wastewater Engineering, 34 (3), 355, 2008 [In Chinese].

32. DENG P.D. Application of mathematical model method in urban rainwater road design. Water \& Wastewater Engineering, 41 (1), 108, 2015 [In Chinese].

33. XU P., HE J.C., REN X.X. Optimization of LID design parameters of urban road based on SWMM model. Water Resources and Power, 34 (2), 21, 2016 [In Chinese].

34. CHEN T., LI Y.W., LI Y. Research on LID technology evaluation of parking lot based on SWMM. Water \& Wastewater Engineering, 40 (5), 155, 2014 [In Chinese]. 
35. LIU X.P. Parameter calibration method for urban rainfallrunoff model based on runoff coefficient. Water \& Wastewater Engineering, 35 (11), 213, 2009 [In Chinese].

36. MCCUEN R.H. Smart growth: hydrologic perspective. Journal of professional issues in engineering education and practice, 129 (3), 151, 2003
37. DAVIS A.P. Field performance of bioretention: hydrology impacts. Journal of Hydrologic Engineering, 13 (2), 90, 2008. 